Article

\title{
Consumption and Emissions Analysis in Domestic Hot Water Hotels. Case Study: Canary Islands
}

\author{
Francisco Javier Díaz Pérez ${ }^{1, * \mathbb{C}}$, Ricardo Díaz Martín ${ }^{2}$, Francisco Javier Pérez Trujillo ${ }^{3}$, \\ Moises Díaz ${ }^{4}$ and Adib Guardiola Mouhaffel ${ }^{5}$ (B) \\ 1 Universidad San Jorge, 50830 Zaragoza, Spain \\ 2 Faculty of Technical Sciences and Engineering, Universidad a Distancia de Madrid (UDIMA), 28400 Madrid, \\ Spain; ricardo.diaz.m@udima.es \\ 3 Department of Chemical and Materials Engineering, Universidad Complutenese de Madrid, 28040 Madrid, \\ Spain; fjperez@quim.ucm.es \\ 4 ESCOEX, Universidad del Atlántico Medio, 35017 Las Palmas de Gran Canaria, Spain; \\ moises.diaz@atlanticomedio.es \\ 5 Electric engineering, Universidad de Las Palmas de Gran Canarias, 35001 Las Palmas de Gran Canaria, \\ Spain; guardiolaadib@gmail.com \\ * Corresponding author: fjdiazp@usj.es
}

Received: 3 January 2019; Accepted: 21 January 2019; Published: 23 January 2019

check for updates

\begin{abstract}
We analyze the energy consumption of domestic hot water (DHW) in the hotels of the archipelago of the Canary Islands (Spain). Currently, systems use fossil fuels of propane and gas oil. However, this paper analyzes several alternative systems which focus on renewable and mixed energies, such as biomass, solar thermal and heat pumps systems associated with an electric generation with photovoltaic solar panels for self-consumption. The carbon footprint generated is calculated for each method of generation of DHW. In our analysis, we demonstrate that by using a high-temperature heat pump with an average coefficient of performance (COP) equal to or greater than 4.4 associated with photovoltaic solar panels, a zero-emission domestic hot water system can be achieved, when the installation area of the photovoltaic solar panels is equal to that of the solar thermal system. The importance of DHW's carbon footprint is proven, as is the efficiency of using high-temperature heat pumps associated with photovoltaic solar panels. As such, such mixed system suggests that the generation of DHW would have zero emissions with maximum annual savings according to hotel occupancy, between 112,417 and 137,644 tons of carbon dioxide $\left(\mathrm{CO}_{2}\right)$, compared to current boilers based on fossil fuels.
\end{abstract}

Keywords: Carbon Footprint; DHW; biomass; photovoltaic; solar thermal; heat pump

\section{Introduction}

One of the major factors of climate change is the emissions of $\mathrm{CO}_{2}$, which mainly originate in natural organic and inorganic processes and by human energy generation [1]. As a result, many countries have introduced measures for energy production and consumption in economic activities. In addition to these energy efficiency measures, of the use of renewable energy systems (EERR) has emerged to achieve zero energy buildings (ZEB) [2] or near zero buildings (nZEB) [3]. It has been demonstrated in several successful projects in buildings around the world, such as the Zero Carbon Building in Hong Kong [4], the Hotel Mongkok Hong Kong [5], the Stadthalle of Vienna [6], or in the hotels of the European Union (EU) Nearly Zero-Energy Hotels (neZEH) project [7], which has achieved an average decrease of $63 \%$ in energy consumption and an increase in the use of EERRs up to 46\% [8].

The $40 \%$ of total energy consumed and $36 \%$ of greenhouse gas emissions in EU correspond to buildings [9], estimating that $79 \%$ of energy is used for heating of water and air conditioning. 
To alleviate this adverse effect, the EU has established short and medium-term objectives [10] for reducing greenhouse gas (GHG) emissions at $20 \%$ for the year 2020, use $20 \%$ of total energy consumption with EERR, for the year 2030 are a reduction of $40 \%$ of emissions in GHG, $27 \%$ of EERR, and an increase in energy efficiency by $27-30 \%$, and as such, it is expected that the EU determines an 80-95\% reduction in GHG emissions for the year 2050, as compared to values in the year 1990. Several directives on the reduction of consumption have been published to achieve these objectives, such as Directive 2010/31/EU [9] on energy efficiency in buildings [11]. Also, Directive 2012/27/EU [12] highlights the importance of promoting the energy efficiency of current and future buildings, with several studies on its application in the EU [13,14].

One of the critical fields of application of these regulations is tourist hotel buildings, because of the significant impact of tourism in society [15]. Tourism worldwide already represents $9 \%$ of the world's GDP, with an income of more than 1400 billion dollars [16], and a continuous increase in income in the last 20 years by $195 \%$, generating $17.6 \%$ of global jobs. In the case of the study area of the archipelago of the Canary Islands (Spain), tourism represents 34.3\% of GDP and generates 39\% of employment [17]. It is worth mentioning that, in the projections of the world tourism organization (UNWTO), the tourist estimates up to the year 2030 include predicted values of 1800 million tourists [18], which doubles the values of 2010 and its associated emissions.

The energy consumptions and emission of a particular hotel can vary according to its geographical area, facilities, and categories of the establishments. For instance, the total energy consumption is divided into $22 \%$ for DHW, $14 \%$ for air conditioning (AC) and $21 \%$ for heating in hotels in Balearic Islands [19]; 31\% for heating, $15 \%$ for AC and 17\% for DHW hotels in the United States [20]; $47 \%$ for heating and 20\% for DHW for hotels in Great Britain [21]; 35\% for heating, $15 \%$ for AC and $22 \%$ for DHW in hotels in Greece [22]. Emissions also vary in establishments worldwide [23]. There is an average emission of $14.6 \mathrm{kgCO}_{2}$ /overnight $\left(\mathrm{CO}_{2} / \mathrm{o}\right)$ in several hotels in the island of Menorca [24], average values of $29 \mathrm{CO}_{2} / \mathrm{o}$ in 58 luxury hotels in Taiwan [25], values between $11.65 \mathrm{CO}_{2}$ /o to $8.25 \mathrm{CO}_{2} / \mathrm{o}$ in hotels in Great Britain [26], and average values of $15.6 \mathrm{CO}_{2} / \mathrm{o}$ in hotels in the Canary Islands [27]. In total, the estimated average for global hotel stays [28] is $20.6 \mathrm{CO}_{2} / \mathrm{o}$.

These values have motivated research on the emissions and consumption associated with the heating of DHW through different heating systems. Some examples are the heat pumps in hotels in the Canary Islands, which reduced energy consumption by 72\% compared to LPG propane boilers [29]. Also, solar thermal systems in hotels in Greece, checking how their energy certification improves and obtaining a reduction of $67 \%$ in its emissions from the DHW [30]. Additionally, a hotel in California (USA) has shown a 33\% energy saving and a return on investment in 4 years [31]. However, other centralized distribution systems using geothermal systems and absorption pumps achieved $100 \%$ utilization of EERR in Germany [32]. Satisfactory results have also been obtained using mixed systems of solar thermal equipment, connected in series with current systems [33]. In this context, we can find mixed systems of electric and solar boilers [34], mixed systems of AC and DHW [35], photovoltaic and thermal solar panels [36], and heat pump systems supplied by photovoltaic solar panels [37].

All of these studies have compared multiple heating systems, both in traditional systems of boilers with fossil fuels or biomass, systems based on solar thermal and mixed systems of heat pumps with power by photovoltaic solar panels. It has allowed for obtaining reference values on the efficiency and emissions of the different systems.

Considering the hotel buildings in Spain, one must take into account their 25\% variation due to seasonal closures, with maximum values of 16,836 hotels for the summer months [38]. Because of these variations, we have focused on a more stable destination, such as the Canary Islands, with 628 hotels offering more than 247,000 hotel beds [39] during the whole year. In this article, we carry out the comparison of these models in current hotel facilities, and in a destination of high ecological value, the sustainability of which is essential and complicated, and with a stable annual hotel occupancy throughout the year. To this end, the case studied is the Canary Islands (Spain), where the 63\% [40] of 
the archipelago's surface is declared a Biosphere Reserve. Thus, results obtained can be applied to other zones of similar geographic and environmental characteristics.

This paper is organized as follows. Section 2 describes the methodology followed in our study. In Section 3 we calculate the required DHW, and its effect on the carbon footprint and the discussion of the results is provided in Section 4. Conclusions are given in Section 5.

\section{Methodology}

As a research area, we have chosen the archipelago of the Canary Islands. It is located in the Mid Atlantic Ocean near the coast of southern Morocco and the Sahara, northern Africa. It has an arid climate, where certain areas have a desert climate or belong to a dry subtropical environment [41], according to the collected data of the open establishments during the year 2017 [20]. Table 1 summarizes the types of existing hotels by category and the current establishment of each class. These average conventional establishments are based on the calculations of energy and water needs; the different fuels and models were converted to the same unit of measurement. It allows for comparison between the generating models, the water in cubic meters $\left(\mathrm{m}^{3}\right)$ and the energy at $\mathrm{kWh}$, transforming the values of the different fuels, according to the primary energy conversion factors for each of them [42,43].

Table 1. Hotels in the Canary Islands and hotel standards by category.

\begin{tabular}{cccccccc}
\hline & Type & 1 Star & 2 Stars & 3 Stars & 4 Stars & 5 Stars & Total \\
\hline \multirow{2}{*}{ Hotels } & Total & 110 & 76 & 149 & 246 & 47 & 628 \\
& Total & 1668 & 3998 & 25,212 & 67,399 & 13,028 & 111,305 \\
\multirow{2}{*}{ Beds } & Standard hotel & 15 & 53 & 169 & 274 & 277 & 177 \\
\multirow{2}{*}{ Rooms } & Total & 3548 & 11,135 & 60,879 & 143,172 & 28,332 & 247,066 \\
& Standard hotel & 32 & 147 & 409 & 582 & 603 & 393 \\
\hline
\end{tabular}

We have studied the DHW needs of the hotel establishments and the $\mathrm{CO}_{2}$ emissions associated with the production of the DHW. Specifically, we followed the workflow shown in Figure 1, which is summarized as follows:

1. Data collection of hotel establishments in the Canary Islands open during the year 2017.

2. Calculation of the standard hotel according to the category of the establishment: places and rooms by category.

3. For each standard hotel of each type, calculation of annual DHW needs per month and the total for all the hotels in the archipelago.

4. With the DHW needs data, the energy required for water heating by category of each standard hotel and the total number of hotels in the Canary Islands.

5. Calculation of the heating system regarding the thermal solar collectors by the F-Chart method $[44,45]$ to cover a minimum of $70 \%$ of the annual thermal needs and the lack of support energy, from the current systems based in fossil energies.

6. The same surface of the solar thermal system is used to install photovoltaic solar panels and the equivalent electrical generation for self-consumption. This energy is used to feed heat pumps, calculating the energy needs for this system.

7. Having in mind the hypothesis that the current technologies are based on fossil fuels of LPG propane and diesel, we calculate the energy needs for this type of boiler and also for biomass boilers with pellet fuel.

8. Carbon footprint comparison in different technologies by category, for all the hotels in the Canary Islands.

9. Conclusions and future needs to achieve sustainable and efficient buildings in terms of the DHW systems in the Canary Islands. 


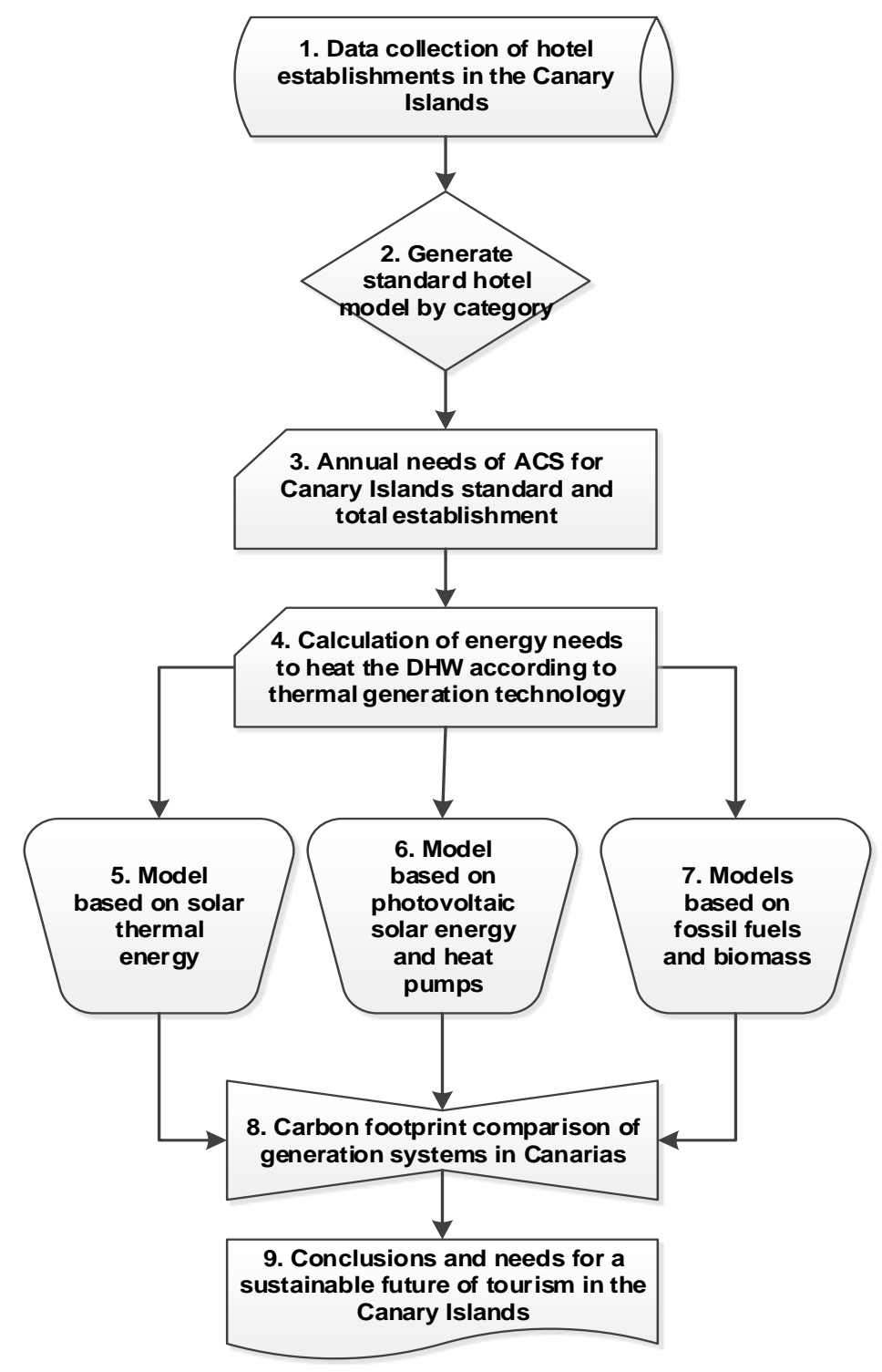

Figure 1. Overview of the research flowchart.

\section{Results: Calculations of DHW's Needs}

The DHW needs calculations is estimated for DHW consumption in the establishment. The tabulated data are used according to the type, category and occupation of establishment [46], which appear in the different regulations and technical guides. We use the standard values of the Spanish Association for Standardization (UNE) 94002:2005 [47] standard, which are closer to the reality of the current buildings that are marked by the latest standards of the technical building code (CTE) in force in Spain $[48,49]$ for new buildings. In Table 2 we compare the consumption data for the calculation. It is observed a gradual decrease, with significant differences of more than $30 \%$ in some cases for new buildings. However, the current ones are calculated with the values of the previous regulations, which have higher consumption values.

The accumulation temperature must be at least $60^{\circ} \mathrm{C}$, due to Legionella regulations [50]. Moreover, we use the Canarias network temperature data from the UNE 94003:2007 standard for Las Palmas de Gran Canaria, the calculations consider the energy losses in the DHW recirculation and return systems, which have been estimated at 10\%. Also, other losses of $5 \%$ have been taken into account. In this way, we obtain the needs for DHW by month and category, for the group of hotels on the islands. According to the UNE 94002:2005 standard, the following Equation (1) is used to calculate the needs for DHW: 


$$
\mathrm{E}_{\mathrm{DHW}}=\left(\mathrm{Q}_{\mathrm{ref}} \cdot \rho \cdot \mathrm{Cp} \cdot\left(\mathrm{T}_{\mathrm{ref}}-\mathrm{T}_{\mathrm{W}}\right)\right) /\left(1-\mathrm{L}_{\mathrm{R}}-\mathrm{L}_{\mathrm{O}}\right)
$$

where " $\mathrm{Q}_{\text {ref" }}$ " refers to the DHW consumption of the hotel type at the reference temperature, " $\rho$ " the water density, "Cp" the specific heat at constant water pressure, " $\mathrm{T}_{\text {ref }}$ " temperature of the DHW for use, " $\mathrm{T}_{\mathrm{W}}$ " water temperature of the network, " $\mathrm{L}_{\mathrm{R}}$ " lost in the hotel network and " $\mathrm{L}_{\mathrm{O}}$ " other losses. The calculus of $\mathrm{E}_{\mathrm{DHW}}$ provides the necessary energy per hotel category and for all of the hotels. Figure 2 shows the increase in energy needs with the increase in the category of hotels and the sum of the energy needs of all hotels in Canary Islands by category, verifying the importance of the consumption of four-star hotels, which represent $61 \%$ of the total the energy needs. The sum of the three main categories of hotels is also made, which represents $96 \%$ of the total energy consumed. Regarding the obtained results, we can conclude that these three top categories require more effort to reduce the energy consumption of the DHW in the Canarias hotel sector.

Table 2. Average unit consumption per room according to different standards by category.

\begin{tabular}{rlccccc}
\hline Normative & & 1 Star & 2 Stars & 3 Stars & 4 Stars & 5 Stars \\
\hline & UNE94002 [46] & 40 & 50 & 60 & 80 & 100 \\
DHW Litters to $60^{\circ} \mathrm{C}$ for bed & CTE 2006 [47] & 35 & 40 & 55 & 70 & 70 \\
& CTE 2017 [48] & 28 & 34 & 41 & 55 & 69 \\
\hline
\end{tabular}

\section{DHW requirements in $\mathrm{kWh}$ by category}

300000000

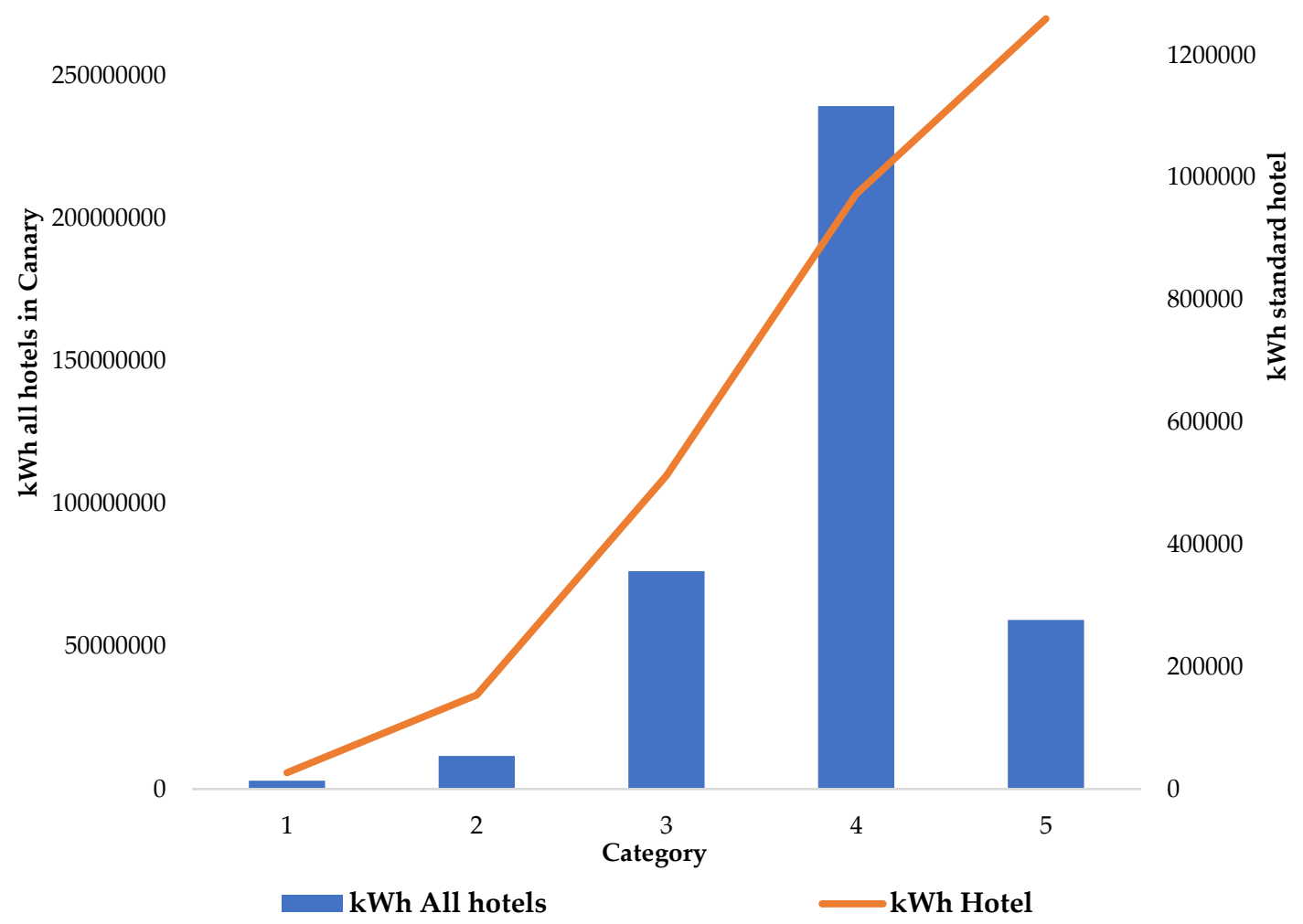

Figure 2. Energy requirements for the domestic hot water (DHW) for each standard hotel and for the entire group of hotels in the Canary Islands by category.

Assuming the calculated data of total energy needs and for each category of hotel, we examine the following heating systems: LPG propane boilers, diesel boilers, biomass boilers with pellets, solar thermal boilers with a support system for boilers LPG propane or diesel current and mixed 
systems of photovoltaic solar generation and heat pumps. Table 3 shows the main characteristics of the photovoltaic and thermal solar panels chosen for the study.

Table 3. Features selected thermal and photovoltaic solar panels.

\begin{tabular}{ccc}
\hline & Photovoltaic & Solar Thermal \\
\hline Model & Atersa A330PGSE & Kairos XPS2.1-1H \\
Surface total $\mathrm{m}^{2}$ & 1.94 & 2.52 \\
Surface solar collector $\mathrm{m}^{2}$ & & 2.241 \\
Coefficient linear losses $\mathrm{Wm}^{2} /{ }^{\circ} \mathrm{K}$ & & 3.015 \\
Coefficient secondary losses $\mathrm{W}^{2} \mathrm{~m}^{2} /{ }^{\circ} \mathrm{K}$ & & 0.017 \\
Optical performance & & 0.812 \\
Maximum power W & 330 & \\
Operating temperature & 45 & \\
Coefficient variation $\mathrm{T}^{\circ}$ & $-0.43 \%$ & \\
\hline
\end{tabular}

\subsection{Thermal Panels Calculations}

The CTE [48] and the Regulation of thermal installations in buildings (RITE) [51] establish that the minimum coverage by EERR for the DHW in the Canary Islands must be 70\%. Therefore, we use it as the minimum value for calculating the thermal solar panels to be installed in the different hotels. The irradiation data that we will use for the calculations are provided by the UNE 94003:2007 standard. The angle of inclination of the panels is a crucial factor. It has significant repercussions for useful radiation, mainly on the surface occupied by the modules. The reason is the minimum separation between rows or obstacles, the value of which is given by the following Equation (2):

$$
\mathrm{D}=\mathrm{L} \cdot \operatorname{sen} \alpha / \operatorname{tg}(61-\mathrm{Lat})
$$

where, " $\mathrm{D}$ " denotes the distance between panels or obstacle, " $\mathrm{L}$ " the height of the obstacle or panel, " $\alpha$ " the inclination of the solar panel and "Lat" the latitude of the installation.

We use the F-Chart method [44,45] to estimate the solar coverage. This method is typically used for the annual thermal performance of heating systems for DHW, in many installations with acceptable forecast results [52]. This method estimates the fraction of thermal energy that will be supplied by solar energy. The primary design variable is the collector area, whereas the secondary variables are: the collector type, the amount of DHW storage and the size of the collector heat exchanger. This method is based on a correlation of the results of many hundreds of thermal performance simulations of solar heating systems. The following Equations (3)-(5) are obtained by using the F-Chart method:

$$
\begin{gathered}
\mathrm{F}=1.029 \mathrm{D}_{1}-0.065 \mathrm{D}_{2}-0.245 \mathrm{D}_{1}^{2}+0.0018 \mathrm{D}_{2}^{2}+0.0215 \mathrm{D}_{1}{ }^{3} \\
\mathrm{D} 1=\operatorname{Fr}(\tau \alpha)_{\mathrm{N}} \frac{\mathrm{F} / \mathrm{r}}{\mathrm{Fr}}\left[\frac{\overline{\tau \alpha}}{(\tau \alpha)_{\mathrm{N}}}\right] \overline{\mathrm{Ht}} \mathrm{N} \frac{\mathrm{Ac}}{\mathrm{L}} \\
\mathrm{D} 2=\operatorname{FrUl} \frac{\mathrm{F} / \mathrm{r}}{\mathrm{Fr}}(\operatorname{Tref}-\mathrm{Ta}) \Delta \mathrm{t} \frac{\mathrm{Ac}}{\mathrm{L}}
\end{gathered}
$$

where, "Ac" is the area of solar collector, " $\mathrm{F}$ ' $\mathrm{r}$ " the collector-heat exchanger efficiency factor, " $\mathrm{Fr}$ " the collector heat removal factor, "UL" the collector overall energy loss coefficient, " $\Delta \mathrm{t}$ " the total number of seconds or hours in the month, "Ta" the monthly average ambient temperature, " $\mathrm{L}$ " the monthly total heating load, "HT" the monthly averaged daily radiation incident on collector surface per unit area, " $\mathrm{N}$ " the number of days in the month, " $\tau \alpha$ " the monthly average transmittance-absorptance product, " $(\tau \alpha)$ " the normal transmittance-absorptance product and "Tref" the reference temperature.

In order to optimize the space and maximize the irradiation with the minimum collector surface, the angle of inclination of the panels is set at $15^{\circ}$. Experimental results for the different inclination values, necessary installation surface and irradiation difference are given in Figure 3 obtained for 
the sum of all hotels the Canary Islands. The chosen angle of inclination of $15^{\circ}$ provides a moderate use surface, since the highest values close to the ideal of $25^{\circ}$ imply that the main surface increases by $15 \%$ and the annual useful irradiation only increases by $0.8 \%$. In addition, this chosen angle helps the evacuation of water and dust, mainly due to the dust of the Sahara or Calima [53,54], which reaches the Canary Islands.

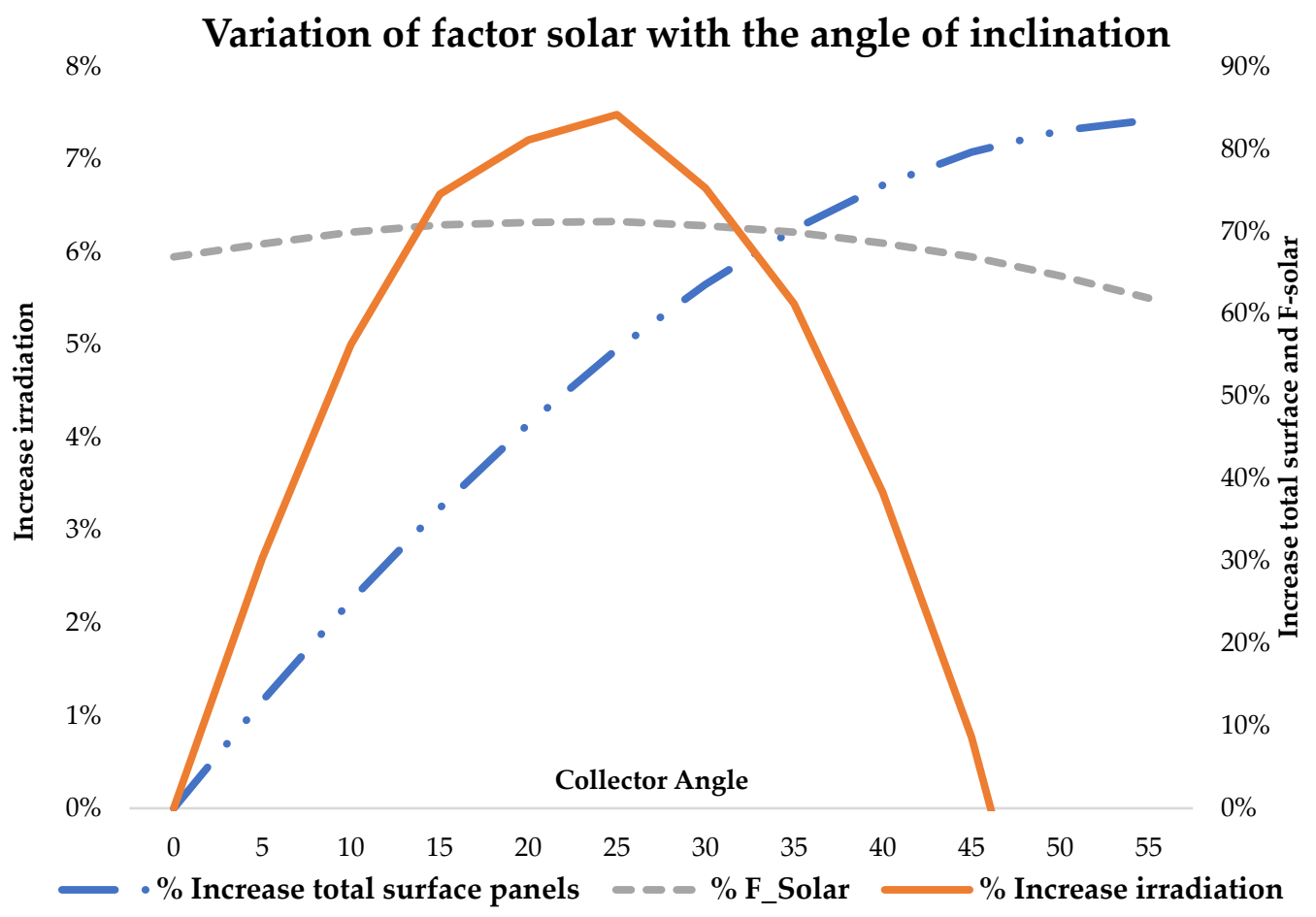

Figure 3. Radiation distance between collectors and solar factor according to the slope of the collectors.

Next, we work out the average values for thermal solar installations. Mainly, we calculate the number of collectors, the surface of the floor used, DHW accumulation needs, the annual solar factor, the thermal energy generated and the missing energy, as it is shown in Table 4 . These values are supposed to be covered by another auxiliary heating system, which in this study will be covered by the existing LPG propane or diesel boilers.

Table 4. Values obtained for thermal solar installations for the standard hotel by category.

\begin{tabular}{ccccccc}
\hline Category & $\begin{array}{c}\mathbf{N}^{\circ} \\
\text { Collectors }\end{array}$ & $\begin{array}{c}\text { Total Surface } \\
\text { Collectors } \mathbf{~ m}^{2}\end{array}$ & Accumulation L & F-Solar \% & $\begin{array}{c}\text { Thermal Energy } \\
\text { Generated kWh }\end{array}$ & $\begin{array}{c}\text { Thermal Energy } \\
\text { Missing kWh }\end{array}$ \\
\hline 5 Stars & 430 & 1479 & 50,000 & $70.4 \%$ & 886,335 & 373,359 \\
4 Stars & 330 & 1135 & 40,000 & $70.2 \%$ & 682,876 & 289,783 \\
3 Stars & 170 & 585 & 30,000 & $70.3 \%$ & 360,280 & 152,371 \\
2 Stars & 50 & 172 & 15,000 & $70.9 \%$ & 108,799 & 44,746 \\
1 Star & 9 & 31 & 2000 & $71.7 \%$ & 19,166 & 7574 \\
\hline
\end{tabular}

Then, we can obtain the needs for all hotels in the Canary Islands. The annual average values of coverage of $70.3 \%$ of annual thermal needs are obtained through thermal solar panels. Figure 4 shows the energy values generated by the thermal solar panels, missing energy that must be covered by the current boilers and the solar fraction obtained monthly, for all the hotels in the Canary Islands. As previously mentioned, the missing energy is supplied by the current LPG propane or diesel boilers. 


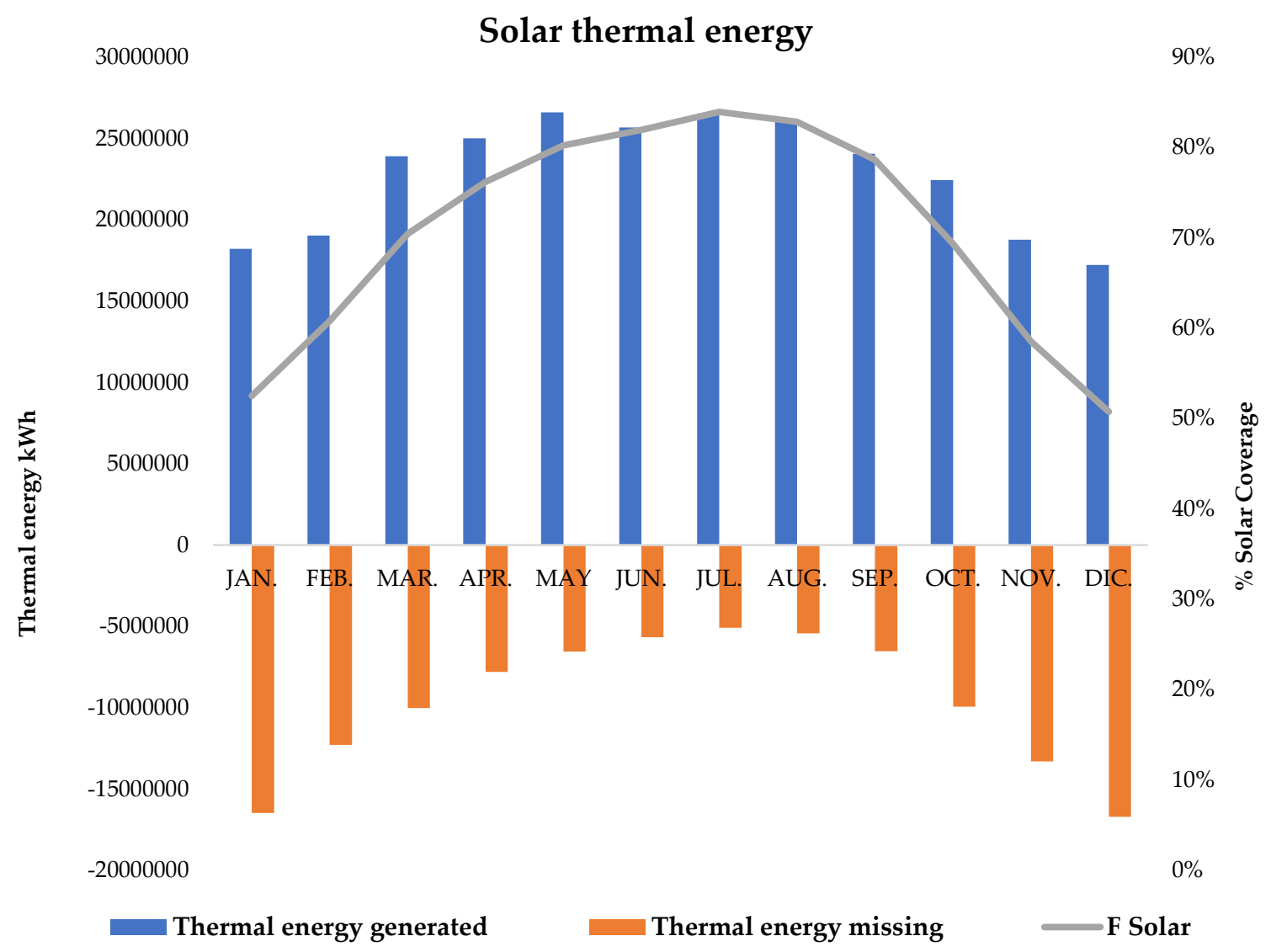

Figure 4. Generation of thermal energy obtained by solar collectors, monthly needs and solar coverage factor for all Canary hotels.

\subsection{Calculations Photovoltaic Panels + Heat Pumps}

Once the available area for solar thermal panes is known, we calculate the photovoltaic solar panels to match the installation surface of solar thermal systems. We aim to occupy the same space in hotel buildings.

On the one hand, the UNE 94003:2007 standard provides the irradiation values of the available area. As such, we deduce the monthly electricity generation of the facilities. Prior studies have used such standards to adjust forecasts to the real generation values [55]. Also, the maximum power of the generator and the total losses must be calculated, which are included in a total efficiency index known as "Performance Ratio" (PR). The following Equation (6) is used to calculate the generation of each installation per month:

$$
\mathrm{E}_{\mathrm{red}}=\mathrm{G}(\beta, \mu) \cdot \mathrm{PR} \cdot \mathrm{P}_{\mathrm{pp}}
$$

where " $G(\beta, \mu)$ " denotes the mean irradiance according to declination and a given azimuth, "PR" the global loss index that encompasses all losses of the system, and " $\mathrm{P}_{\mathrm{pp}}$ " the maximum power of photovoltaic generators. PR is obtained by considering all the losses of the generating system, which is given by the Equation (7):

$$
\mathrm{PR}=\left(1-\left(\mathrm{L}_{\mathrm{T}}+\mathrm{L}_{\mathrm{D}}+\mathrm{L}_{\mathrm{R}}+\mathrm{L}_{\mathrm{P}}\right)\right) \cdot \mathrm{L}_{\mathrm{E}} \cdot \mathrm{L}_{\mathrm{In}} \cdot \mathrm{L}_{\mathrm{V}}
$$

where, " $\mathrm{L}_{\mathrm{T}}$ " denotes the losses by temperature, calculated by the method of Osterwald [56]. " $\mathrm{L}_{\mathrm{D}}$ " refers to the losses by dispersion of parameters $(2 \%)$, " $\mathrm{L}_{\mathrm{R}}$ " the losses by angular and spectral reflectance $(3 \%)$, " $\mathrm{L}_{\mathrm{P}}$ " the losses due to dust on the modules $(3 \%)$ and in the Canary Islands due to the episodes of Calima. The latter parameter is essential since it may arise higher values whether the modules are not cleaned regularly, Also, " $\mathrm{L}_{\mathrm{E}}$ " denotes the efficiency in electrical wiring $(97 \%)$, " $\mathrm{L}_{\mathrm{IN}}$ " the efficiency 
due to the efficiency of the inverter (94\%). In our case, we use the European efficiency value [57] of the inverter given by the manufacturer. Finally, " $\mathrm{L}_{V}$ " is another efficiency parameter, that was not previously considered (97\%).

The same angle of inclination $\left(15^{\circ}\right)$ previously set in the thermal solar panels as the occupied surface by category, is used in photovoltaic modules. This is so that the number of photovoltaic solar panels and the maximum installed power are calculated. Table 5 shows the values obtained for electricity generation for standard hotels by category, monthly and annual total.

Table 5. Monthly and annual electricity generation in kWh by hotel according to the category.

\begin{tabular}{ccccccc}
\hline & CATEGORY & 1 Star & 2 Stars & 3 Stars & 4 Stars & 5 Stars \\
\hline & N $^{\circ}$ Collectors & 12 & 65 & 220 & 430 & 560 \\
& Used surface m $^{2}$ & 32 & 172 & 582 & 1138 & 1483 \\
& Installed power kW & 3.96 & 21.45 & 72.6 & 141.9 & 184.8 \\
& JAN. & 404 & 2189 & 7410 & 14,484 & 18,863 \\
& FEB. & 422 & 2285 & 7734 & 15,116 & 19,686 \\
& MAR. & 538 & 2915 & 9,865 & 19,282 & 25,111 \\
& APR. & 568 & 3075 & 10,408 & 20,343 & 26,493 \\
Electricity generation & MAY & 615 & 3329 & 11,268 & 22,024 & 28,682 \\
in kWh & JUN. & 597 & 3236 & 10,954 & 21,410 & 27,883 \\
& JUL. & 618 & 3347 & 11,328 & 22,141 & 28,835 \\
& AUG. & 603 & 3267 & 11,057 & 21,612 & 28,146 \\
& SEP. & 544 & 2948 & 9978 & 19,502 & 25,398 \\
& OCT. & 498 & 2698 & 9131 & 17,846 & 23,242 \\
& NOV. & 417 & 2259 & 7647 & 14,947 & 19,465 \\
& DIC. & 385 & 2087 & 7065 & 13,808 & 17,983 \\
& TT & 6210 & 33,636 & 113,845 & 222,515 & 289,787 \\
\hline
\end{tabular}

Then, we calculate the water heating system for DHW based on heat pump by using monthly and annual generation data. For this purpose, different heat pump efficiencies with COP values are used. We start with a minimum value of 2 for older equipment up to a maximum of 8 for more modern equipment. Modern equipment has optimum operating conditions and high-efficiency dissipation systems by aerothermal, geothermal or hydrothermal. Figure 5 shows the results for the total energy requirements for hotels in the Canary Islands. It is observed that systems with a COP equal to 4.4 produce zero emissions and equipment with a higher COP consume less energy than that generated by photovoltaic systems. The energy left over could be used for self-consumption producing a general decrease in emissions from hotel establishments. It is also verified that the characteristic function that describes the curve of necessary or excess energy of the heat pumps concerning the efficiency of the machines corresponds to a logarithmic function, which has a very high correlation index for all its values.

$$
\mathrm{E}=-46771 \cdot \ln (\mathrm{COP})+120321
$$

We calculate the consumption of heat pumps for all hotels in the Canary Islands. To this end, we check whether the photovoltaic solar panels help to supply the energy necessary to cover the needs of the DHW, except from October to February, which require an external supply. However, the annual demand for electricity is covered by the total amount of energy generated in the remaining months from March to September. Figure 6 shows the photovoltaic generation obtained and the surplus or lack of electrical energy to cover the needs of heat pumps with an average COP of 4.4, monthly. 


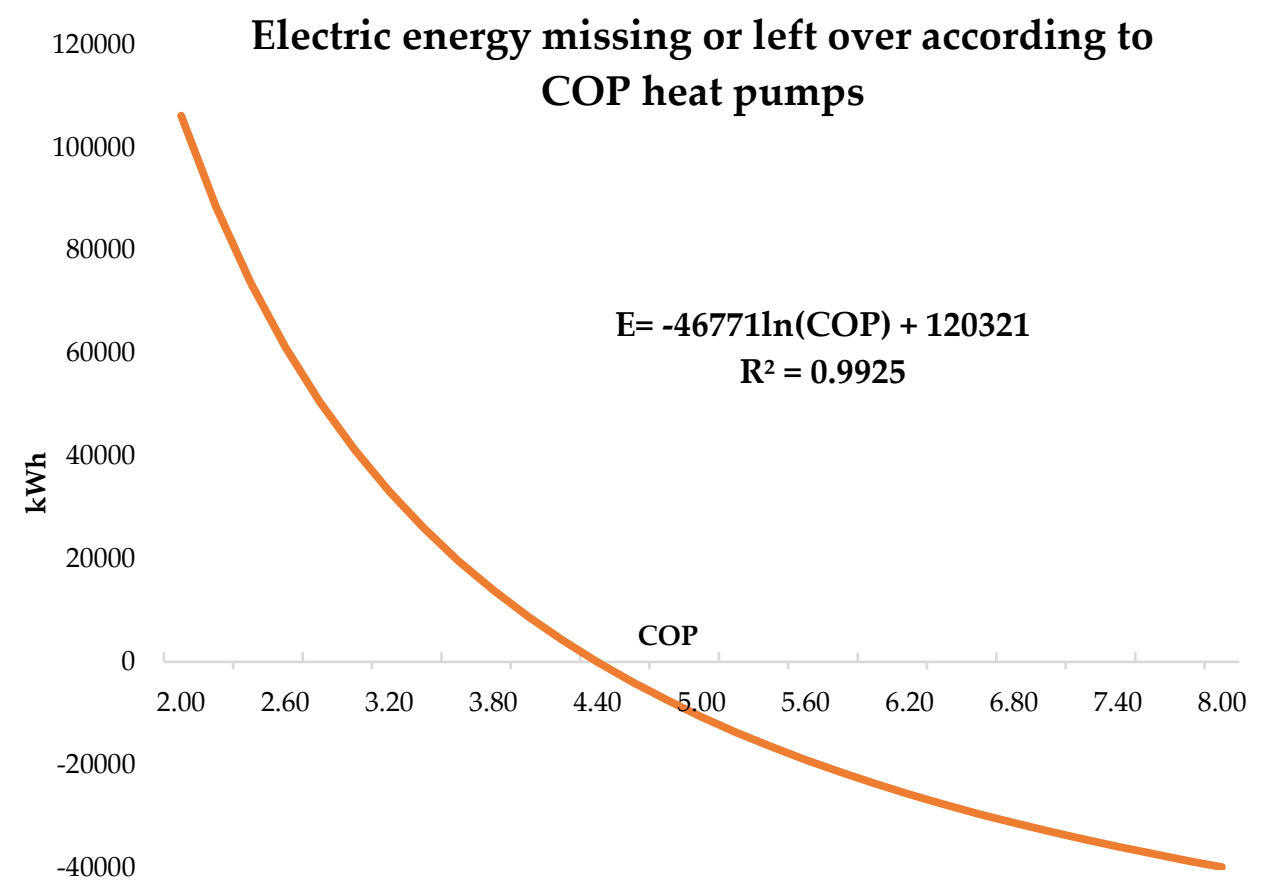

Figure 5. Values of energy generated by the solar panels for DHW heating using heat pumps according to the coefficient of performance (COP) efficiency of the equipment used.

Photovoltaic generation and heat pumps COP 4.4

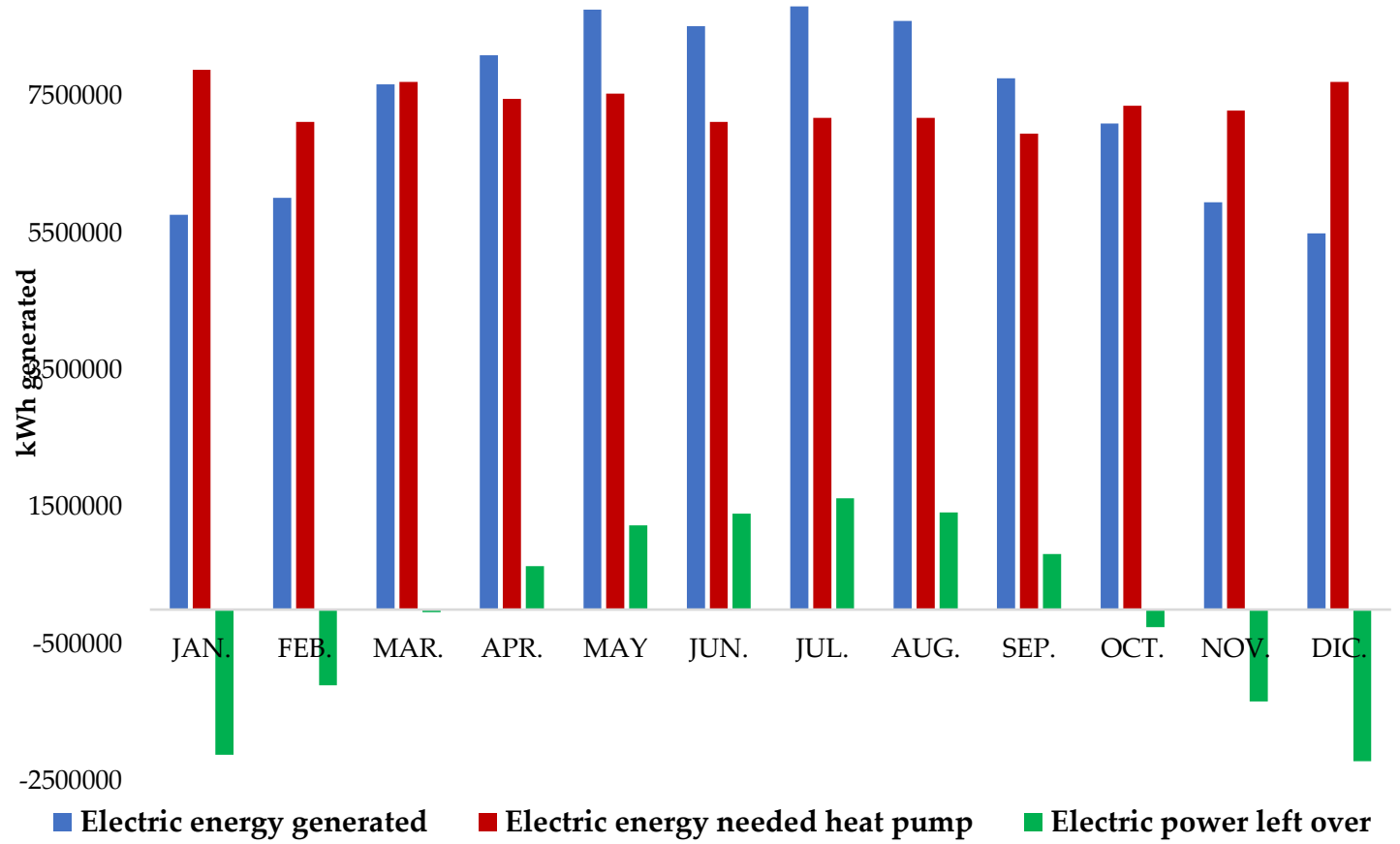

Figure 6. Photovoltaic generation and energy need of heat pumps, as well as the surplus or lack of monthly energy for all hotels in the Canary Islands.

\subsection{Fossil Combustible Calculations and Biomass}

Systems based on fossil fuels such as LPG, propane or diesel and biomass are used to calculate energy needs. Correctly, we use the average efficiency for all boiler operating regimes, with an estimated value of $88 \%$. To quantify fuel requirements, the conversion coefficients of the different fuels converted 
to kWh are used. We show these values in Table 6, according to the Institute for Energy Diversification and Saving (IDAE) [42].

Table 6. Conversion factors of different fuels.

\begin{tabular}{cc}
\hline Fuels & Conversion Factors \\
\hline Diesel & $10.28 \mathrm{kWh} / \mathrm{L}$ \\
LPG Propane & $12.75 \mathrm{kWh} / \mathrm{kg}$ \\
Pellet in general & $4.57 \mathrm{kWh} / \mathrm{kg}$ \\
\hline
\end{tabular}

In Table 7 we show the number of necessary fuels per month as well as the total year values to heat the DHW for all hotels in the Canary Islands. They are obtained once the energy needs, the efficiency of the boilers and calorific value of the fuels, are obtained.

Table 7. Needs of fossil fuels and pellets for all hotels in the Canary Islands.

\begin{tabular}{cccc}
\hline & $\begin{array}{c}\text { Pellet } \\
\text { kg }\end{array}$ & $\begin{array}{c}\text { LPG Propane } \\
\text { kg }\end{array}$ & $\begin{array}{c}\text { Diesel } \\
\text { L }\end{array}$ \\
\hline JAN. & $8,627,078$ & $3,092,215$ & $3,835,189$ \\
FEB. & $7,792,200$ & $2,792,969$ & $3,464,042$ \\
MAR. & $8,435,365$ & $3,023,500$ & $3,749,963$ \\
APR. & $8,163,257$ & $2,925,967$ & $3,628,996$ \\
MAY & $8,243,653$ & $2,954,784$ & $3,664,737$ \\
JUN. & $7,792,200$ & $2,792,969$ & $3,464,042$ \\
JUL. & $7,860,227$ & $2,817,352$ & $3,494,284$ \\
AUG. & $7,860,227$ & $2,817,352$ & $3,494,284$ \\
SEP. & $7,606,671$ & $2,726,470$ & $3,381,565$ \\
OCT. & $8,051,940$ & $2,886,068$ & $3,579,510$ \\
NOV. & $7,977,728$ & $2,859,468$ & $3,546,519$ \\
DIC. & $8,435,365$ & $3,023,500$ & $3,749,963$ \\
Year & $96,845,911$ & $34,712,613$ & $43,053,094$ \\
\hline
\end{tabular}

\section{Discussion. The DHW Carbon Footprint}

The energy needs of the different heating models and the previously calculated fuel needed are used to analyze the emissions associated with the different systems studied. We calculate the carbon footprint of the different heating systems, as the European Commission regulations suggest using multiple models and existing standards [58]. In our study, we have used the Greenhouse Gases Protocol (GHG) [59], widely used by organizations around the world. Scopes 1 and 2 of fuels and electricity were calculated for heating the DHW. We quantify the emission factors and the $\mathrm{CO}_{2}$ emission values, which are approved and updated for Spain were used [42]. They are given in Table 8, the emission factors of electricity changes yearly or even monthly. In this way, we estimate emissions with the average emission data from the last year 2017 [60] and if all hotels have own transformer, with a medium voltage supply that generates losses of $6 \%$ in medium voltage lines.

Table 8. Emission factors of different fuels and electricity.

\begin{tabular}{cc}
\hline Fuel & $\mathrm{CO}_{2}$ Emission Factors \\
\hline Diesel & $0.311 \mathrm{~kg} / \mathrm{kWh}$ \\
LPG Propane & $0.254 \mathrm{~kg} / \mathrm{kWh}$ \\
Pellet in general & $0.018 \mathrm{~kg} / \mathrm{kWh}$ \\
Electricity in the Canary Islands & $0.827 \mathrm{~kg} / \mathrm{kWh}$ \\
\hline
\end{tabular}

Taking into account these emission factors, and the energy needs according to the fuels, the emissions of each of the water heating systems are calculated. The calculation is based on the category of hotel and 
for all the hotels in the Canary Islands. Table 9 summarizes the energy needs by category, the associated emissions by hotel and for the total number of hotels, showing the total value of energy needs and emissions for all the hotels in the Canary Islands. It can be seen how the mixed system of heat pumps with a minimum COP of 4.4 and photovoltaic solar panels cover all the energy needs of the DHW system, suggesting a zero emissions system. In addition, the case study generates excess energy, which could be used in the self-consumption of hotel facilities. Category 2- and 3-star hotels are the only shortfalls in total annual energy, which is why it is necessary to carry out support with external energy supply. The proposed mixed system stops emissions, with maximum annual savings according to hotel occupancy, between 112,417 to 137,644 tons of $\mathrm{CO}_{2}$, which are emitted by current heating systems based on fossil fuels.

Figure 7 compares the total emissions of all hotels in the Canary Islands. It can be seen that the system based on the mixed model of photovoltaic solar energy and heat pumps produces zero emissions with the same surface area of collectors as solar thermal systems. Systems based on biomass boilers are the following with the lowest emissions. However, one difficulty of the study area is the carbon footprint generated by the transport of pellets to the Canary Islands, which is very high because of transportation issues [61].

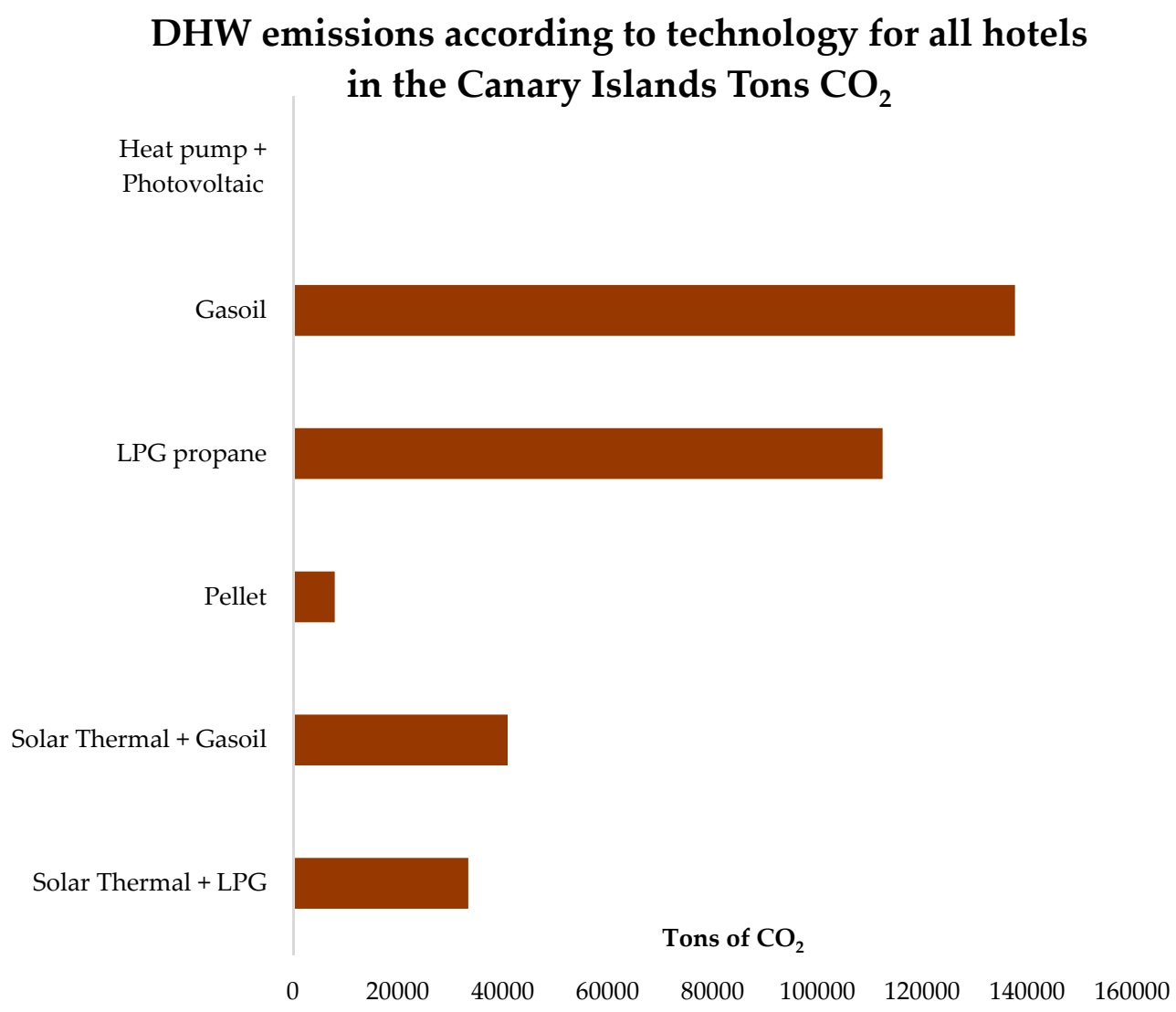

Figure 7. Summary of emissions due to DHW of the different technologies used for all the hotels of the Canary Islands. 
Table 9. Summary of energy needs and emissions of the different heating models of DHW by hotel and for all the hotels of the Canary Islands.

\begin{tabular}{|c|c|c|c|c|c|c|c|c|c|}
\hline \multirow{2}{*}{\multicolumn{2}{|c|}{ Hotel Category, Type of Fuel and Emissions }} & \multicolumn{2}{|c|}{ Solar Thermal } & \multirow{2}{*}{$\begin{array}{c}\text { Pellet } \\
\text { kg }\end{array}$} & \multirow{2}{*}{$\begin{array}{c}\text { LPG Propane } \\
\mathrm{kg}\end{array}$} & \multirow{2}{*}{$\begin{array}{c}\text { Gasoil } \\
\text { L }\end{array}$} & \multirow{2}{*}{$\begin{array}{c}\text { Photovoltaic } \\
\text { kWh }\end{array}$} & \multirow{2}{*}{$\begin{array}{c}\begin{array}{c}\text { Heat Pump } \\
\text { COP } 4.4\end{array} \\
\mathrm{kWh}\end{array}$} & \multirow{2}{*}{$\begin{array}{c}\text { Heat Pump + } \\
\text { Photovoltaic } \\
\text { kWh }\end{array}$} \\
\hline & & $\begin{array}{c}+\mathrm{LPG} \\
\text { Propane Kg }\end{array}$ & +Gasoil L & & & & & & \\
\hline \multirow{4}{*}{1 Star } & Hotel Fuel & $675 \mathrm{~kg}$ & $837 \mathrm{~L}$ & $6649 \mathrm{~kg}$ & $2383 \mathrm{~kg}$ & $2956 \mathrm{~L}$ & $6210 \mathrm{kWh}$ & $6077 \mathrm{kWh}$ & $-133 \mathrm{kWh}$ \\
\hline & Total fuel & $74,255 \mathrm{~kg}$ & $92,097 \mathrm{~L}$ & $731,394 \mathrm{~kg}$ & $262,155 \mathrm{~kg}$ & $325,143 \mathrm{~L}$ & $683,070 \mathrm{kWh}$ & $668,494 \mathrm{kWh}$ & $-14,576 \mathrm{kWh}$ \\
\hline & Hotel $\mathrm{kg} \mathrm{CO} 2$ & 2186 & 2677 & 547 & 7718 & 9450 & -5134 & 5025 & -110 \\
\hline & Total kg CO 2 & 240,476 & 294,441 & 60,164 & 848,987 & $1,039,508$ & $-564,762$ & 552,711 & $-12,052$ \\
\hline \multirow{4}{*}{2 Stars } & Hotel Fuel & $3988 \mathrm{~kg}$ & $4946 \mathrm{~L}$ & $38,180 \mathrm{~kg}$ & $13,685 \mathrm{~kg}$ & $16,973 \mathrm{~L}$ & $33,636 \mathrm{kWh}$ & $34,897 \mathrm{kWh}$ & $1260 \mathrm{kWh}$ \\
\hline & Total fuel & $303,090 \mathrm{~kg}$ & $375,915 \mathrm{~L}$ & $2,901,681 \mathrm{~kg}$ & $1,040,053 \mathrm{~kg}$ & $1,289,950 \mathrm{~L}$ & $2,556,339 \mathrm{kWh}$ & $2,652,136 \mathrm{kWh}$ & $95,798 \mathrm{kWh}$ \\
\hline & Hotel $\mathrm{kg} \mathrm{CO} 2$ & 12,915 & 15,814 & 3141 & 44,319 & 54,264 & $-27,810$ & 28,852 & 1042 \\
\hline & Total $\mathrm{kg} \mathrm{CO}$ & 981,558 & $1,201,829$ & 238,692 & $3,368,213$ & $4,124,072$ & $-2,113,581$ & $2,192,786$ & 79,206 \\
\hline \multirow{4}{*}{3 Stars } & Hotel Fuel & $13,580 \mathrm{~kg}$ & $16,843 \mathrm{~L}$ & $127,474 \mathrm{~kg}$ & $45,691 \mathrm{~kg}$ & $56,669 \mathrm{~L}$ & $113,845 \mathrm{kWh}$ & $116,512 \mathrm{kWh}$ & $2667 \mathrm{kWh}$ \\
\hline & Total fuel & $2,023,468 \mathrm{~kg}$ & $2,509,651 \mathrm{~L}$ & $18,993,699 \mathrm{~kg}$ & $6,807,937 \mathrm{~kg}$ & 8,443,697 L & $16,962,910 \mathrm{kWh}$ & $17,360,241 \mathrm{kWh}$ & $397,330 \mathrm{kWh}$ \\
\hline & Hotel $\mathrm{kg} \mathrm{CO} 2$ & 43,980 & 53,849 & 10,486 & 147,970 & 181,176 & $-94,127$ & 96,332 & 2205 \\
\hline & Total $\mathrm{kg} \mathrm{CO}$ & $6,553,000$ & $8,023,555$ & $1,562,422$ & $22,047,505$ & $26,995,174$ & $-14,024,934$ & $14,353,447$ & 328,513 \\
\hline \multirow{4}{*}{4 Stars } & Hotel Fuel & $25,827 \mathrm{~kg}$ & $32,033 \mathrm{~L}$ & $241,859 \mathrm{~kg}$ & $86,690 \mathrm{~kg}$ & $107,519 \mathrm{~L}$ & $222,515 \mathrm{kWh}$ & $221,059 \mathrm{kWh}$ & $-1456 \mathrm{kWh}$ \\
\hline & Total fuel & $6,353,521 \mathrm{~kg}$ & 7,880,096 L & $5,949,7236 \mathrm{~kg}$ & $21,325,676 \mathrm{~kg}$ & $26,449,647 \mathrm{~L}$ & $54,738,762 \mathrm{kWh}$ & $54,380,474 \mathrm{kWh}$ & $-358,288 \mathrm{kWh}$ \\
\hline & Hotel $\mathrm{kg} \mathrm{CO}_{2}$ & 83,642 & 102,412 & 19,895 & 280,745 & 343,746 & $-183,976$ & 182,771 & -1204 \\
\hline & Total $\mathrm{kg} \mathrm{CO}$ & $20,575,877$ & $25,193,298$ & $4,894,243$ & $69,063,202$ & $84,561,637$ & $-45,258,009$ & $44,961,776$ & $-296,233$ \\
\hline \multirow{4}{*}{5 Stars } & Hotel Fuel & $33,276 \mathrm{~kg}$ & $41,272 \mathrm{~L}$ & $313,232 \mathrm{~kg}$ & $112,272 \mathrm{~kg}$ & $139,248 \mathrm{~L}$ & $289,787 \mathrm{kWh}$ & $286,294 \mathrm{kWh}$ & $-3493 \mathrm{kWh}$ \\
\hline & Total fuel & $1,563,981 \mathrm{~kg}$ & 1,939,762 L & $14,721,901 \mathrm{~kg}$ & $5,276,791 \mathrm{~kg}$ & $6,544,658 \mathrm{~L}$ & $13,620,006 \mathrm{kWh}$ & $13,455,817 \mathrm{kWh}$ & $-164,189 \mathrm{kWh}$ \\
\hline & Hotel $\mathrm{kg} \mathrm{CO}_{2}$ & 107,765 & 131,948 & 25,766 & 363,593 & 445,187 & $-239,596$ & 236,708 & -2888 \\
\hline & Total kg CO & $5,064,952$ & $6,201,575$ & $1,211,024$ & $17,088,888$ & $20,923,796$ & $-11,261,021$ & $11,125,270$ & $-135,751$ \\
\hline \multirow{2}{*}{ TOTAL } & Fuel & $10,318,315 \mathrm{~kg}$ & $12,797,521 \mathrm{~L}$ & $96,845,911 \mathrm{~kg}$ & $34,712,613 \mathrm{~kg}$ & $43,053,094 \mathrm{~L}$ & $88,561,087 \mathrm{kWh}$ & $88,517,162 \mathrm{kWh}$ & $43,925 \mathrm{kWh}$ \\
\hline & $\mathrm{kg} \mathrm{CO}_{2} \mathrm{TT}$ & $33,415,862$ & $40,914,698$ & $7,966,545$ & $112,416,796$ & $137,644,187$ & $-73,222,307$ & $73,185,990$ & $-36,317$ \\
\hline
\end{tabular}




\section{Conclusions}

In this paper, we have assessed more efficient and less polluting systems in energy consumption in hotels. Specifically, we have focused on DHW, since it is one of the primary energy consumers. We have studied different possibilities of generation of DHW using systems based on renewable energy and compared them with current energy generation systems based on fossil fuels. Our analysis of solar thermal and photovoltaic systems, sharing the same collector surfaces, suggested that the most profitability energy generation is the combination of photovoltaic generation and heat pumps. Such a combination led to better results regarding efficient and harmful emissions. Also, improvements in the energy autonomy of the buildings for heating the DHW were observed, reducing its external energy dependence and the carbon footprint associated with tourism.

The models based on solar thermal energy have proven the problem associated with the need for a second source of energy to cover the total demand of the system, which increases the need for investment and external energy dependence.

As such, our study also suggests that benefits are obtained when self-generation through photovoltaic solar panels. Such solar panels are associated with heat pumps with higher COP efficiency values. As such, our study also suggests that benefits are obtained when self-generation through photovoltaic solar panels, and we demonstrate that using high-temperature heat pump with an average COP equal to or greater than 4.4 associated with photovoltaic solar panels, a zero-emission DHW can be achieved, when the installation area of the photovoltaic solar panels was equal to that for solar thermal system. When solar panels are associated with heat pumps with higher COP efficiency values, it entails higher savings and very fast amortizations of the systems, improving, therefore, the efficiency of equipment and the effectiveness of current photovoltaic solar panels, this being the main direction for achieving the energy independence of these buildings.

Finally, the Canary Islands is a sensitive and vulnerable tourist destination, with great external energy dependence and great ecological value. Toward a more efficient technological use of this technology and reduction in the pollution, we plan to develop the experimental improvements of this study in existing buildings in our future works. As has been demonstrated in the studied context, the use of EERR is an excellent way to achieve the goal of converting current buildings into ZEB or nZEB, based on improvements in current DHW heating systems.

Author Contributions: Formal analysis, F.J.D.P., R.D.M., M.D., F.J.P.T. and A.G.M.; Investigation, F.J.D.P., R.D.M. and F.J.P.T.; Writing-review and editing, F.J.D.P., M.D. and A.G.M.

Funding: This research received no external funding.

Conflicts of Interest: The authors declare no conflict of interest.

\section{References}

1. IPCC. Climate Change 2013: The Physical Science Basis. Contribution of Working Group I to the Fifth Assessment Report of the Intergovernmental Panel on Climate Change; Cambridge University Press: Cambridge, UK; New York, NY, USA, 2013; 1535p, ISBN 978-1-107-66182-0.

2. Attia, S.; Mlecnik, E.; Van Loon, S. Net zero energy building: A review of current definitions and definition development in Belgium. In Proceedings of the Passive House Symposium 2011, Brussels, Belgium, 7 October 2011.

3. Crawley, D.; Pless, S.; Torcellini, P. Getting to net zero. ASHRAE J. 2009, 51, 18-25.

4. ZCB. Zero Carbon Building (ZCB) Hong Kong. Available online: http://zcb.hkcic.org/Eng/index.aspx (accessed on 10 December 2017).

5. Cheung, M.; Fan, J. Carbon reduction in a high-density city: A case study of Langham Place Hotel Mongkok Hong Kong. Renew. Energy 2016, 50, 433-440. [CrossRef]

6. Stadthalle, Hotel. Available online: https://www.hotelstadthalle.at/es/ (accessed on 10 December 2017).

7. Tournaki, S.; Frangou, M.; Tsoutsos, T.; Morell, R.; Guerrero, I.; Urosevic, Z.; Derjanecz, A.; Núñez, C.; Rata, C.; Bišćan, M.; et al. Towards Nearly Zero Energy Hotels. Technical Analysis and Recommendations. 
neZEH. In Proceedings of the 5th International Conference on Renewable Energy Sources and Energy Efficiency, Nicosia, Cyprus, 5-6 May 2016.

8. Tsoutsos, T.; Tournaki, S.; Frangou, M.; Tsitoura, M. Creating paradigms for nearly zero energy hotels in South Europe. AIMS Energy 2017, 6, 1-18. [CrossRef]

9. EU. Directive 2010/31/EU of the Parliament of Europe and the Council of May 19, 2010, realizing the energy efficiency of buildings. Off. J. EU 2010, L 153, 13-35.

10. EU. Energy. Available online: https://europa.eu/european-union/topics/energy_es (accessed on 12 March 2018).

11. Kraus, M.; Kubečková, D. Airtightness of Energy Efficient Buildings. GSTF Int. J. Eng. Technol. 2013, 2, 74-80. [CrossRef]

12. EU. Directive 2012/27/EU of the Parliament of Europe and of the Council of October 25, 2012, relating to energy efficiency, by which the Directives 2009/125/EC and 2010/30/EU are modified, and repealing Directives 2004/8/EC and 2006/32/EC. Off. J. EU 2012, L 315, 1-56.

13. Bánya, O.; Fodor, L. Energy efficiency obligation schemes in the energy efficiency directive-An environmental assessment. Environ. Eng. Manag. J. 2014, 13, 2749-2755. [CrossRef]

14. Zīgurs, A.; Sarma, U. Implementation of the Energy Efficiency Directive-Opportunities and Challenges. Latv. J. Phys. Tech. Sci. 2015, 52, 3-12. [CrossRef]

15. UNWTO. Tourism Highlights, 2017 ed.; UNWTO: Madrid, Spain, 2017.

16. UNWTO. UNWTO Panorama of International Tourism, 2015 ed.; UNWTO: Madrid, Spain, 2015.

17. Exeltur. Impactur Canarias 2016; Study of the Economic Impact of Tourism on the Economy and Employment in the Canary Islands; Exeltur: Madrid, Spain, 2017.

18. UNWTO. Tourism towards 2030. Global Overview; UNWTO: Madrid, Spain, 2011; ISBN 13-978-92-844-1399-7.

19. Moiá-Pol, A.; Karagiorgas, M.; Coll-Mayor, D.; Martínez-Moll, V.; Riba-Romeva, C. Evaluation of the Energy Consumption in Mediterranean islands Hotels: Case study: The Balearic Islands Hotels. Renew. Energy Power Qual. J. 2005, 1, 106-110. [CrossRef]

20. HES. Best Practices Guide-Successful Renewable Energy Technologies Integration in SME Hotels; Hotel Energy Solutions Project Publications: Madrid, Spain, 2011; eISBN: 978-92-844-1499-4.

21. The Carbon Trust. Hospitality, Saving Energy without Compromising Service; The Carbon Trust: London, UK, 2015.

22. Karagiorgas, M.; Tsoutsos, T.; Moiá-Pol, A. A simulation of the energy consumption monitoring in Mediterranean hotels: Application in Greece. Energy Build. 2007, 39, 416-426. [CrossRef]

23. Chong, H.; Ricaurte, E.E. Hotel Sustainability Benchmarking Tool 2015: Energy, Water, and Carbon. Cornell Hosp. Rep. 2015, 15, 6-11.

24. Sanyé-Mengual, E.; Romanos, H.; Molina, C.; Oliver, M.A.; Ruiz, N.; Pérez, M.; Carreras, D.; Boada, M.; Garcia-Orellana, J.; Duch, J.; et al. Environmental and self-sufficiency assessment of the energy metabolism of tourist hubs on Mediterranean Islands: The case of Menorca (Spain). Energy Policy 2014, 65, 377-387. [CrossRef]

25. Yao, Z.; Zhuang, Z.; Gu, W. Study on Energy Use Characteristics of Hotel Buildings in Shanghai. Procedia Eng. 2015, 121, 1977-1982. [CrossRef]

26. Filimonau, V.; Dickinson, J.; Robbins, D.; Huijbregts, M.A. Reviewing the carbon footprint analysis of hotels: Life Cycle Energy Analysis (LCEA) as a holistic method for carbon impact appraisal of tourist accommodation. J. Clean. Prod. 2011, 19, 1917-1930. [CrossRef]

27. Pérez, F.J.D.; Chinarro, D.; Mouhaffel, A.G.; Martín, R.D.; Otín, M.R.P. Comparative study of carbon footprint of energy and water in hotels of Canary Islands regarding mainland Spain. Environ. Dev. Sustain. 2018. [CrossRef]

28. Gössling, S.; Peeters, P.; Ceron, J.P.; Dubois, G.; Patterson, T.; Richardson, R.B. The eco-efficiency of tourism. Ecol. Econ. 2005, 54, 417-434. [CrossRef]

29. Díaz Pérez, F.J.; Chinarro, D.; Otín, M.R.P.; Díaz, R. Reduction of Energy Consumption in Hotels with Aerothermal Energy. Case Study: Canary Islands (Spain). Int. J. Eng. Technol. 2018, 7, 127-131. [CrossRef]

30. Kyriaki, E.; Giama, E.; Papadopoulou, A.; Drosou, V.; Papadopoulos, A.M. Energy and Environmental Performance of Solar Thermal Systems in Hotel Buildings. Procedia Environ. Sci. 2017, 38, 36-43. [CrossRef]

31. Delgado, R.; Campbell, H.E. Adaptation and Sizing of Solar Water Heaters in Desert Areas: For Residential and Hotels. Energy Procedia 2014, 57, 2725-2732. [CrossRef] 
32. Østergaard, P.A.; Lund, H. A renewable energy system in Frederikshavn using low-temperature geothermal energy for district heating. Appl. Energy 2011, 88, 479-487. [CrossRef]

33. Hang, Y.; Qu, M.; Zhao, F. Economic and environmental life cycle analysis of solar hot water systems in the United States. Energy Build. 2012, 45, 181-188. [CrossRef]

34. Mondol, J.D.; Smyth, M. Comparative Performance Analysis of Solar Heat Exchangers for Solar Hot Water Systems. In Proceedings of the EuroSun 2012, Rijeka, Croatia, 18-20 September 2012.

35. Chen, Y.; Treado, S. Development of a simulation platform based on dynamic models for HVAC control analysis. Energy Build. 2014, 68, 376-386. [CrossRef]

36. Da Silva, R.M.; Fernandes, J.L.M. Hybrid photovoltaic/thermal (PV/T) solar systems simulation with Simulink/Matlab. Sol. Energy 2010, 84, 1985-1996. [CrossRef]

37. Tsai, H. Design and evaluation of a Photovoltaic/Thermal-assisted heat pump water heating system. Energies 2014, 7, 3319-3338. [CrossRef]

38. Statistics National Institute (INE). Available online: http:/ / www.ine.es/ (accessed on 10 February 2018).

39. Canary Institute of Statistics (ISTAC). Available online: http://www.gobiernodecanarias.org/istac/ (accessed on 10 February 2018).

40. Government of the Canary Islands. Environmental Information System of the Canary Islands; The Canarias Reserve Network of the Biosphere; Government of the Canary Islands: Canary Islands, Spain, 2016.

41. Teresa García Muñoz. Inbound international tourism to Canary Islands: A dynamic panel data model. Tour. Manag. 2006, 27, 281-291. [CrossRef]

42. IDAE. Heat Powers. Update 21 July 2014. Available online: http://www.idae.es/uploads/documentos / documentos_PCI_Combustibles_Carburantes_final_valores_Update_2014_0830376a.xlsx (accessed on 18 April 2018).

43. Government of Spain. $\mathrm{CO}_{2}$ Emission Factors and Primary Energy Passage Coefficients of Different Final Energy Sources Consumed in the Building Sector in Spain; Ministries of Industry, Energy and Tourism, and Ministry of Development: Madrid, Spain, 2016.

44. Klein, S.A.; Beckman, W.A.; Duffie, J.A. A design procedure for solar heating systems. Sol. Energy 1976, 18, 113-127. [CrossRef]

45. Klein, S.A.; Beckman, W.A. A general design method for closed-loop solar energy systems. Sol. Energy 1979, 22, 269-282. [CrossRef]

46. Hiller, C.; Johnson, R. Hot-Water Use in Hotels: Part 5-Updated Hotel Hot-Water System Design Techniques. ASHRAE Trans. 2017, 123, 160.

47. Spanish Association for Standardization, UNE 94002:2005. Thermal Solar Systems for Domestic Hot Water Production. Calculation Method for Heat Demand; AENOR: Madrid, Spain, 2005.

48. Government of Spain, Ministry of Housing. RD 314/2006, of March 17, which approves the Technical Building Code. BOE 2006, 74, 11816-11831.

49. Government of Spain, Ministry of Development. Basic document of energy saving HE with indicated modifications of Order FOM/588/2017, of June 15, by which the Basic Document DB-HE “Energy Saving" and the Basic Document DB-HS “Healthiness" are modified, of the Technical Building Code, approved by Royal Decree 314/2006, of March 17. BOE 2017, 149, 51621-51624.

50. Government of Spain, Ministry of the Presidency. Royal Decree 865/2003, of July 4, establishing the hygienic-sanitary criteria for the prevention and control of legionellosis. BOE 2003, 171, 28955-28969.

51. Government of Spain, Ministry of the Presidency. Royal Decree 1027/2007, of July 20, which approves the Regulation of Thermal Installations in Buildings. BOE 2007, 207, 35931-35984.

52. Okafo, I.F.; Akubue, G. F-Chart Method for Designing Solar Thermal Water Heating Systems. Int. J. Sci. Eng. Res. 2012, 3, 1-7.

53. Alonso-Pérez, S.; Cuevas, E.; Querol, X.; Guerra, J.C.; Pérez, C. African dust source regions for observed dust outbreaks over the Subtropical Eastern North Atlantic region, above $25^{\circ}$ N. J. Arid Environ. 2012, 78, 100-109. [CrossRef]

54. Viana, M.; Querol, X.; Alastuey, A.; Cuevas, E.; Rodriguez, S. Influence of African dust on the levels of atmospheric particulates in the Canary Islands air quality network. Atmos. Environ. 2002, 36, 5861-5875. [CrossRef]

55. Perez, F.J.D.; Chinarro, D.; Mouhaffel, A.G.; Martin, R.D.; Otin, M.R.P. Assement Solar Database Regarding Production Values in Fuerteventura Photovoltaic Installations. Indian J. Sci. Technol. 2017, 10, 1-16. [CrossRef] 
56. Osterwald, C.R. Translation of device performance measurements to reference conditions. Sol. Cells 1986, 18, 269-279. [CrossRef]

57. International Electrotechnical Commission. IEC 61215/2016. Crystalline Silicium Terrestrial Photovoltaic (PV) Modules_Design Qualification and Type Approval; International Electrotechnical Commission (IEC): Geneva, Switzerland, 2016.

58. Chomkhamsri, K.; Pelletier, N. Analysis of Existing Environmental Footprint Methodologies for Products and Organizations: Recommendations, Rationale, and Alignment Deliverable; European Commission (EC) Joint Research Centre (JRC) Institute for Environment and Sustainability (IES): Ispra, Italy, 2011.

59. World Resources Institute (WRI) and World Business Council for Sustainable Development (WBSCSD). The Greenhouse Gas Protocol. A Corporate Accounting and Reporting Standard; WBSCSD: Geneve, Switzerland, 2009; ISBN 1-56973-568-9. Available online: https:/ / ghgprotocol.org/ (accessed on 22 June 2018).

60. Red Eléctrica de España. Spanish Electricity Network (REE). The Spanish Electricity System 2017; Red Eléctrica de España (REE): Madrid, Spain, 2016.

61. Martín, R.D.; Contreras, G.S.; Mouhaffel, A.G. Analysis of Production, Transport and Lifecycle of Pellets. Am. J. Environ. Prot. 2015, 4, 91-94. [CrossRef]

(C) 2019 by the authors. Licensee MDPI, Basel, Switzerland. This article is an open access article distributed under the terms and conditions of the Creative Commons Attribution (CC BY) license (http:/ / creativecommons.org/licenses/by/4.0/). 